\title{
Plankton community respiration along a nutrient gradient in a shallow Danish estuary
}

\author{
Lillian Magelund Jensen*, Kaj Sand-Jensen, Steen Marcher, Mads Hansen
}

Freshwater Biological Laboratory, University of Copenhagen, Helsingersgade 51, DK-3400 Hillerød, Denmark

\begin{abstract}
Plankton community respiration was examined in a shallow, very eutrophic Danish estuary during April to September. Maximum rates $\left(3.98 \mathrm{~g} \mathrm{O}_{2} \mathrm{~m}^{-3} \mathrm{~d}^{-1}\right)$ were measured during the phytoplankton spring bloom in the most eutrophicated inner parts. Community respiration was significantly related to biomass and gross productivity of phytoplankton and net production of bacterioplankton. The relationship was weak to temperature and bacterial biomass. Regression analysis suggested that phytoplankton and bacteria, on average, accounted for 64 to $83 \%$ of the community respiration at the 2 most eutrophic localities. The regressions also provided estimates of mean phytoplankton respiration $\left(0.76 \mathrm{mg} \mathrm{O}_{2} \mathrm{mg}^{-1}\right.$ chlorophyll a $\mathrm{h}^{-1}, 6.0 \%$ of gross productivity), mean bacterial respiration (1.4 times net production) and mean bacterial growth yield ( $42 \%$ ). Pelagic respiration exceeded benthic respiration and became proportionally larger with increasing eutrophication and phytoplankton productivity in the inner parts of the estuary. These results stress the importance of phytoplankton blooms for pelagic respiration, overall oxygen balances and oxygen depletion phenomena.
\end{abstract}

\section{INTRODUCTION}

Oxygen consumption during respiratory degradation of organic compounds in plankton communities is the essential counterpart to photosynthetic carbon assimilation. Photosynthetic and respiratory rates define the trophic status of pelagic environments and the difference between them describes the actual export or degradation of imported organic compounds.

Traditionally, the emphasis on pelagic metabolism has been on primary productivity because of the ease of ${ }^{14} \mathrm{C}$-measurements compared with the difficult and less sensitive respiratory measurements (Williams 1984). Technical improvements of dissolved oxygen measurements by electrodes and Winkler titration (Talling 1973, Bryan et al. 1976, Griffith 1984, Langdon 1984) now allow sensitive measurements of dark oxygen consumption even in oligotrophic waters.

The eutrophication problems emerging worldwide in coastal marine waters, and the associated risk of severe oxygen depletion phenomena, have accentuated the need for accurate measurements and robust predictions of pelagic oxygen consumption. Many estuaries and coastal waters now experience severe oxygen

- Present address: Institute of Biology and Chemistry, University of Roskilde, PO Box 260, DK-4000 Roskilde, Denmark depletion episodes every year resulting in profound changes in the abundance of many marine species including several of economic importance (Anon. 1984, Officer et al. 1984, Larsson et al. 1985). Oxygen consumption has increased both in the water column and the sediment of eutrophicated regions, and pelagic respiration is frequently the dominant process (Westernhagen et al. 1986)

Several functional groups of organisms are involved in plankton community respiration. Direct respiration measurements in size-fractions have shown high activities of phytoplankton and bacteria (Williams 1981). Measurements of high biomass and net production of free-living bacteria subsequently led to the realization that a large proportion of primary productivity is channeled through the microbial food webs of bacteria and heterotrophic flagellates (Azam et al. 1983, Fenchel 1988) in addition to the direct macrozooplankton-fish food chain (Steele 1974).

Respiratory processes in oceanic waters and in coastal waters without substantial input of easily degradable organic compounds from land and benthic plants rely on photosynthetic products from phytoplankton. Dark respiration of phytoplankton is linearly related to their growth rate (cf. Langdon 1988), and thus to their photosynthetic output, and bacterial metabolism is greatly dependent on utilization of extracellular products of 
photosynthetic origin (cf. Larsson \& Hagström 1979. 1982). Because phytoplankton and bacteria are usually the main respiring organisms and zooplankton contributes much less to plankton community respiration (Williams 1984) we would anticipate a close coupling between phytoplankton productivity and community respiration. This coupling is also facilitated in the shallow estuary examined here because the water column is without any permanent thermo- or halocline (Borum 1985).

Biomass and productivity of phytoplankton and bacteria are therefore likely to be good descriptors of plankton community respiration. For bacteria the coupling to production should be closer than to biomass because of the presence of a variable and often large proportion of inactive bacteria, and because active bacteria have variable turnover rates (Riemann et al. 1984).

We examined plankton community respiration at 4 locations along a nutrient gradient in the highly eutrophic Roskilde Fjord. Our purposes were to describe levels and seasonal variations of community respiration and to analyze the relationship to biomass and productivity of phytoplankton and bacteria. An empirical regression model of community respiration was used to estimate the proportions of phytoplankton and bacterial respiration. Finally, plankton community respiration was compared with plankton primary productivity and benthic respiration to assess the overall oxygen balance of the water column and the sediments.

\section{MATERIALS AND METHODS}

Study sites. Roskilde Fjord is a narrow, shallow and soft-bottom estuary connected with Kattegat via the outer part of Isefjord, Denmark (Fig. 1). The tidal amplitude is less than $10 \mathrm{~cm}$. We examined 4 locations situated in natural basins from the less saline (ca $10 \%$ ) and very nutrient-rich inner part (Stn 1) to the more saline (ca $19 \%$ ) and less nutrient-rich outer part (Stn 4) (Table 1). Concentrations of inorganic-nitrogen were very high in winter and early spring following run-off from surrounding agricultural areas and concentrations declined greatly after the spring bloom of planktonic diatoms (Table 1 in Borum 1985). Concentrations of inorganic-phosphate were never limiting to algal growth and concentrations increased during summer due to release from sediments (Table 1 in Borum 1985).

Water sampling. Water was collected with a 51 perspex sampler from 3 depths (Stn 1) and 4 depths (Stns 2, 3 and 4) evenly distributed in the shallow water column (4.1 to $8.0 \mathrm{~m}$. Table 1). Community respiration was measured at every depth but other variables were measured on integrated samples. Measurements of temperature, salinity, chemical and biological variables

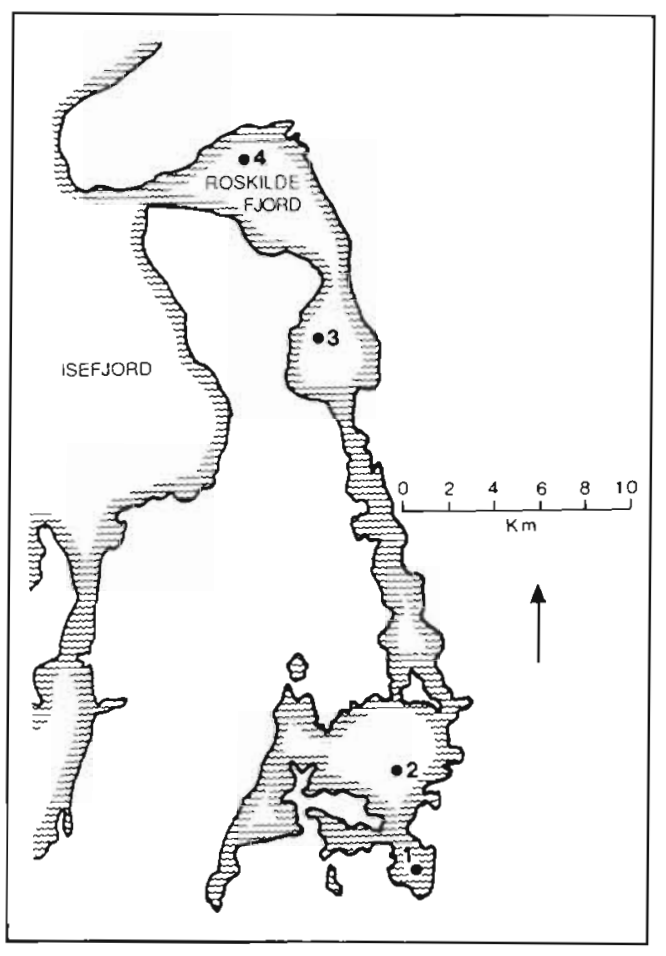

Fig. 1 Map of Roskilde Fjord, Denmark, indicating the 4 sampling stations located in basins from the inner to the outer part

usually showed no changes with depth through the water column during this and previous investigations (Borum 1985). During calm periodes, however, depth changes were sometimes observed particularly for community respiration. Samples were collected between 10:00 and 14:00 $\mathrm{h}$ and measurements were started immediately (community respiration) or within 1 to $4 \mathrm{~h}$.

Community respiration. Water samples were transferred to a darkened 51 perspex cylinder, thoroughly mixed and equipped with a floating lid to avoid oxygen exchange during the following procedure. Water was siphoned via a gas-tight tube through the lid and into $125 \mathrm{ml}$ darkened Jena glass bottles. Bottles were incubated under water in dark thermoboxes filled with ambient seawater during transport and subsequently under circulation in a thermostated incubator in the laboratory. The bottles were incubated for $24 \mathrm{~h}$ at in situ temperature $\left( \pm 1^{\circ} \mathrm{C}\right)$. The initial and final concentrations of oxygen were measured on duplicate bottles, from every depth, with a micro-Winkler technique using starch as a visible indicator of the endpoint. We calculated the mean community respiration for the water column from the 3 or 4 sets of measurements with depth each consisting of 2 initial and 2 final oxygen bottles. The precision of the method required a difference between initial and final samples of $32 \mathrm{mg} \mathrm{O}_{2} \mathrm{~m}^{-3}$ 
to be significant at the $95 \%$ confidence limit. This is similar to the sensitivity reported by Schwaerter et al. (1988) using amperometric endpoint detection. Oxygen consumption rates were much higher in the estuary, between 220 and $3980 \mathrm{mg} \mathrm{O}_{2} \mathrm{~m}^{-3} \mathrm{~d}^{-1}$.

Bacterial biomass and net production. Bacteria cell numbers and mean volumes were determined by epifluorescence microscopy on formalin fixed preparations stained with acridine orange (Hobbie et al. 1977). Samples were treated by a deflocculant and by ultrasound before filtration, following Velji (1983), to ensure a more even distribution of bacteria on the filter. The bacterial cells were counted in duplicate samples in several microscopic fields $(>10)$ containing a total of ca 200 cells. Cell volume was measured 3 times during the investigation by photography of acridine orange preparations compared with filtrates of $1.0 \mu \mathrm{m}$ latex spheres. The dimensions of bacteria were measured (length and width) and the volume calculated following Fuhrman (1981). Cell volume varied considerably within each sample and there were no significant differences with time and among stations. We used a mean cell volume of $0.063 \mathrm{um}^{3}$ in subsequent calculations of biomass and production of bacteria. Biovolume was converted to carbon biomass by a conversion factor, $0.35 \mathrm{pg} \mathrm{C} \mathrm{mm}^{-3}$, found for this particular estuary (Bjørnsen 1986).

Bacterial net production was measured by $\left({ }^{3} \mathrm{H}\right)$ thymidine incorporation into cold trichloroacetic acid (TCA) precipitate (Fuhrman \& Azam 1980). Triplicate samples of $25 \mathrm{ml}$ were incubated with $7.8 \mathrm{nM}$ (methyl${ }^{3} \mathrm{H}$ ) thymidine for $30 \mathrm{~min}$, fixed by $1 \%$ formalin, and $10 \mathrm{ml}$ subsamples were filtered onto $0.45 \mu \mathrm{m}$ cellulose nitrate filters. The filters were washed 5 times with $1 \mathrm{ml}$ $5 \%$ ice-cold TCA and radioassayed by liquid scintillation counting (Riemann 1984). Triplicate blanks prefixed with formalin were treated like the samples. $\left({ }^{3} \mathrm{H}\right)$ thymidine incorporation was converted into cell production applying an empirical factor, $1.1 \times 10^{18}$ cells produced per mol thymidine, determined in the estuary (Riemann et al. 1987), and into carbon production by

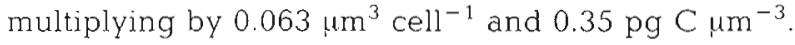

Phytoplankton biomass and gross productivity. Phytoplankton biomass as chlorophyll a was measured by ethanol extraction of duplicate filtered samples (Jespersen \& Christoffersen 1987). Primary production was measured by ${ }^{14} \mathrm{C}$-incorporation into particulate material in 25 to $30 \mathrm{ml}$ glass bottles in an incubator at in situ temperature following recommendations in Nielsen et al. (1981) and Anon. (1983). Bottles were incubated for 2 $\mathrm{h}$ in duplicate at photon flux densities between 0 and $547 \mu \mathrm{E} \mathrm{m}^{-2} \mathrm{~s}^{-1}$ provided by fluorescent light tubes. Dissolved inorganic carbon was measured on an infrared gas analyzer (Vermaat \& Sand-Jensen 1987). Conversion of incubator measurements to in situ estimates of daily primary productivity was based on continuous measurements of surface photon flux density $(400$ to $700 \mathrm{~nm}$ ) at Hydrotechnical Laboratory close to Roskilde Fjord and measurements of the vertical diffusive attenuation coefficient of photons $(400$ to 700 $\mathrm{nm}$ ) through the water column at every sampling date.

\section{RESULTS}

\section{Light, temperature and plankton community structure}

Roskilde Fjord has high nutrient levels, high light attenuation and high biomass and productivity of phytoplankton and bacteria (Tables 1 and 2). Moreover, there is a clear gradient in trophic status from the inner (Stn 1) to the outer parts (Stn 4). Mean levels of phytoplankton biomass and gross productivity declined 5 to 6 -fold along the gradient; bacterial net production

Table 1. Water depth $(\mathrm{m})$, light attenuation $\left(\mathrm{K}_{\mathrm{T}}, \mathrm{ln}\right.$ units $\left.\mathrm{m}^{-1}\right)$ and nutrient concentrations (mg $\mathrm{m}^{-3}$ ) measured at 4 stations in Roskilde Fjord. Seasonal mean value and range of diffusive photon attenuation coefficient ( $K_{T}$; Jensen et al. 1987) was measured 21 times (Stns 1 and 2), 8 times (Stn 3) and 9 times (Stn 4) between April 15 and September 2. Nutrient concentrations (KampNielsen \& Kanneworff unpubl. data) were measured 8 to 10 times between April 15 and September 2

\begin{tabular}{|c|c|c|c|c|}
\hline Variable & Stn 1 & $\operatorname{Stn} 2$ & $\operatorname{Stn} 3$ & $\operatorname{Stn} 4$ \\
\hline Mean depth & 4.1 & 4.6 & 5.6 & 8.0 \\
\hline $\mathrm{K}_{\mathrm{T}}$ & $\begin{array}{c}1.36 \\
0.70-6.44\end{array}$ & $\begin{array}{c}0.94 \\
0.37-3.85\end{array}$ & $\begin{array}{c}0.63 \\
0.43-0.88\end{array}$ & $\begin{array}{c}0.49 \\
0.36-0.69\end{array}$ \\
\hline $\mathrm{NH}_{4}^{+}+\mathrm{NO}_{3}^{-}-\mathrm{N}$ & $\begin{array}{l}482 \\
5-843\end{array}$ & $\begin{array}{l}181 \\
2-459\end{array}$ & $\begin{array}{c}116 \\
15--355\end{array}$ & $\begin{array}{c}62 \\
13-147\end{array}$ \\
\hline Total-N & $\begin{array}{c}1655 \\
1163-2982\end{array}$ & $\begin{array}{c}1305 \\
152-2194\end{array}$ & $\begin{array}{c}944 \\
623-1278\end{array}$ & $\begin{array}{c}766 \\
444-1089\end{array}$ \\
\hline $\mathrm{PO}_{4}^{-3}-\mathrm{P}$ & $\begin{array}{c}638 \\
333-909\end{array}$ & $\begin{array}{c}514 \\
193-814\end{array}$ & $\begin{array}{c}199 \\
52-324\end{array}$ & $\begin{array}{c}64 \\
15-140\end{array}$ \\
\hline Total-P & $\begin{array}{c}713 \\
234-997\end{array}$ & $\begin{array}{c}549 \\
163-906\end{array}$ & $\begin{array}{c}228 \\
76-374\end{array}$ & $\begin{array}{c}82 \\
24-131\end{array}$ \\
\hline
\end{tabular}


Table 2. Community respiration ( $\mathrm{mg} \mathrm{O}_{2} \mathrm{~m}^{-3} \mathrm{~h}^{-1}$ ), phytoplankton biomass ( $\mathrm{mg} \mathrm{chl} \mathrm{a} \mathrm{m}^{-3}$ ), phytoplankton gross productivity at light saturation ( $\left.\mathrm{mg} \mathrm{C} \mathrm{m}{ }^{3} \mathrm{~h}^{-1}\right)$, bacterial biomass $\left(\mathrm{mg} \mathrm{C} \mathrm{m}{ }^{-3}\right)$ and bacterial net production $\left(\mathrm{mg} \mathrm{Cm}^{-3} \mathrm{~h}^{-1}\right)$ at $\mathrm{Stns} 1(\mathrm{n}=21), 2(\mathrm{n}=21)$, $3(n=8)$ and $4(n=9)$ in Roskilde Fjord. Coefficients of variation (CV) for 59 pairs of measurements $(C V=S D / x)$. Seasonal mean values and ranges of measurements between April 15 and September 2. (For community respiration the number of duplicates was 207)

\begin{tabular}{|c|c|c|c|c|c|}
\hline Variable & Stn 1 & $\operatorname{Stn} 2$ & Stn 3 & Stn 4 & $\mathrm{CV}(\%)$ \\
\hline Community respiration & $\begin{array}{c}59.6 \\
11.7-165.8\end{array}$ & $\begin{array}{c}34.3 \\
10.0-117.1\end{array}$ & $\begin{array}{c}22.5 \\
9.2-42.5\end{array}$ & $\begin{array}{c}22.9 \\
9.6-61.3\end{array}$ & $\begin{array}{l}10.4 \\
0-75\end{array}$ \\
\hline Phytoplankton biomass & $\begin{array}{c}39.9 \\
7.7-165\end{array}$ & $\begin{array}{c}14.2 \\
3.2-103\end{array}$ & $\begin{array}{c}7.2 \\
1.8-20.2\end{array}$ & $\begin{array}{c}7.0 \\
4.6-15.6\end{array}$ & $\begin{array}{c}2.9 \\
0-17\end{array}$ \\
\hline Phytoplankton gross productivity & $\begin{array}{c}172.9 \\
35.8-362\end{array}$ & $\begin{array}{c}69.4 \\
12.4-360\end{array}$ & $\begin{array}{c}45.4 \\
10.6-129\end{array}$ & $\begin{array}{c}28.9 \\
17.1-44.6\end{array}$ & $\begin{array}{c}4.8 \\
0-29\end{array}$ \\
\hline Bacterial biomass & $\begin{array}{c}251 \\
32-240\end{array}$ & $\begin{array}{c}210 \\
67-389\end{array}$ & $\begin{array}{c}192 \\
74-326\end{array}$ & $\begin{array}{c}107 \\
53-148\end{array}$ & $\begin{array}{l}12.4 \\
0.27\end{array}$ \\
\hline Bacterial net production & $\begin{array}{c}5.8 \\
1.6-11.0\end{array}$ & $\begin{array}{c}3.6 \\
0.62-7.3\end{array}$ & $\begin{array}{c}2.0 \\
1.0-3.5\end{array}$ & $\begin{array}{c}1.5 \\
0.57-2.2\end{array}$ & $\begin{array}{c}8.0 \\
0-34\end{array}$ \\
\hline
\end{tabular}

declined 4-fold; and bacterial biomass dropped 2.5fold. The reproducibility of these measurements was high, i.e. the mean coefficients of variation (CV) of the duplicate measurements were 2.9, 4.8, 8.0 and $12.4 \%$ respectively (Table 2 ).

The seasonal patterns of surface light, water temperature and phytoplankton biomass are shown in Figs. 2 and 3 . Water temperatures increased from ca $5^{\circ} \mathrm{C}$ in mid April to ca $17^{\circ} \mathrm{C}$ in mid June and fluctuated about this value until September (Fig. 2). Phytoplankton biomass showed a pronounced spring bloom at all 4 locations shortly after the ice disappeared and declined to 3 to 4 -fold lower summer levels (Fig. 3).

\section{Community respiration and correlation among variables}

Community respiration was very high in the estuary and followed the same gradient as biomasses and productivities of phytoplankton and bacteria (Table 2). Mean community respiration was $59.6 \mathrm{mg} \mathrm{O}_{2} \mathrm{~m}^{-3} \mathrm{~h}^{-1}$ (1430 $\mathrm{mg} \mathrm{O}_{2} \mathrm{~m}^{-3} \mathrm{~d}^{-1}$ ) at Stn 1 and almost 3-fold lower at $\operatorname{Stn} 4$ (22.9 $\left.\mathrm{mg} \mathrm{O}_{2} \mathrm{~m}^{-3} \mathrm{~h}^{-1} ; 550 \mathrm{mg} \mathrm{O}_{2} \mathrm{~m}^{-3} \mathrm{~d}^{-1}\right)$. The maximum community respiration occurred during the phytoplankton spring bloom attaining levels of 166 and $117 \mathrm{mg} \mathrm{O}_{2} \mathrm{~m}^{-3} \mathrm{~h}^{-1}$ (3980 and $2810 \mathrm{mg} \mathrm{O}_{2} \mathrm{~m}^{-3} \mathrm{~d}^{-1}$ ) at Stns 1 and 2, respectively (Fig. 4). The reproducibility of community respiration measurements was high, with a mean CV of only $10.4 \%$ (Table 2).

Simple correlation analysis based on 59 measurements at all 4 locations between April 15 and September 2 showed that community respiration was significantly correlated with phytoplankton biomass ( $\mathrm{r}=$ $0.79)$, phytoplankton productivity $(\mathrm{r}=0.68)$ and bacterial net production $(r=0.59)$, but not with bacterial

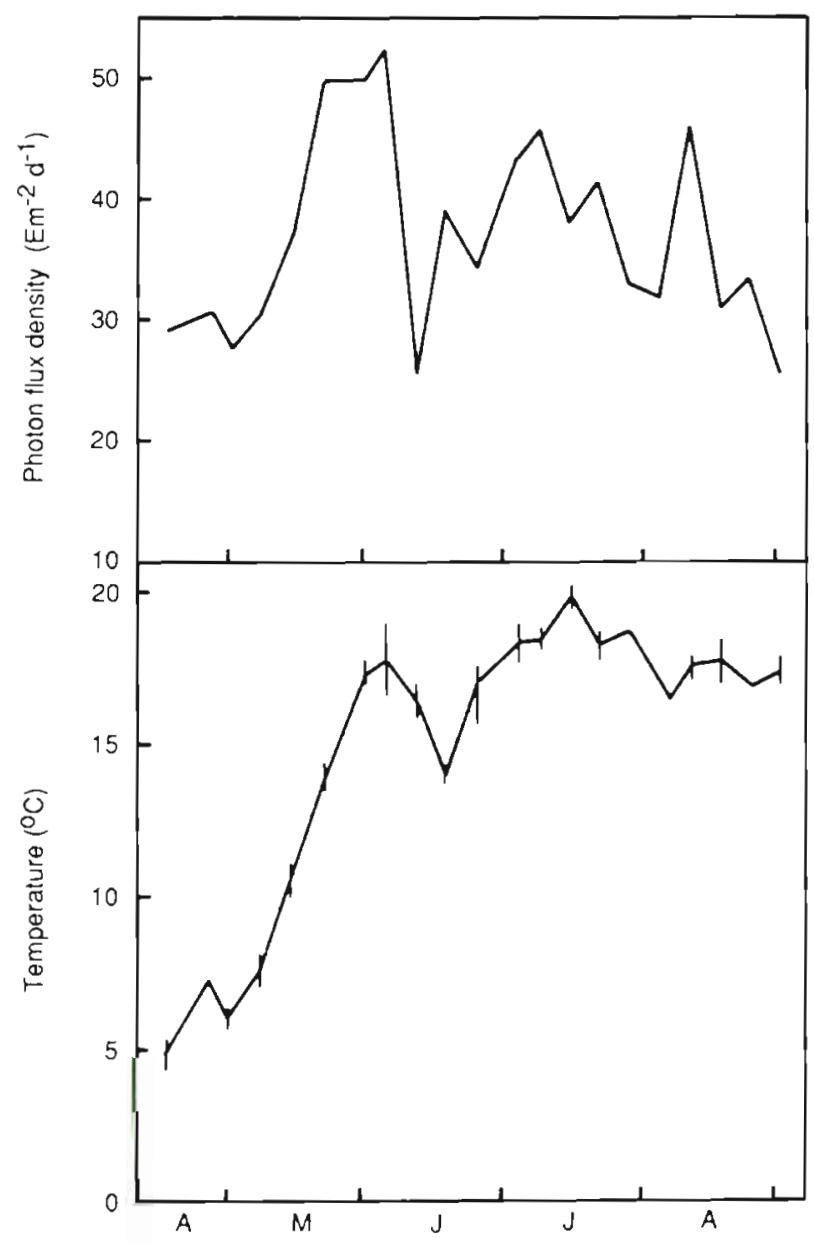

Fig. 2. Surface light (upper) and water temperature (lower) in Roskilde Fjord between April 15 and September 2. Surface light was measured as photon flux density $(400$ to $700 \mathrm{~nm})$ at the nearby Hydrotechnical Laboratory and daily values were averaged over $7 \mathrm{~d}$. Water temperature is the mean and range at all 4 locations between 10:00 and 15:00 h 


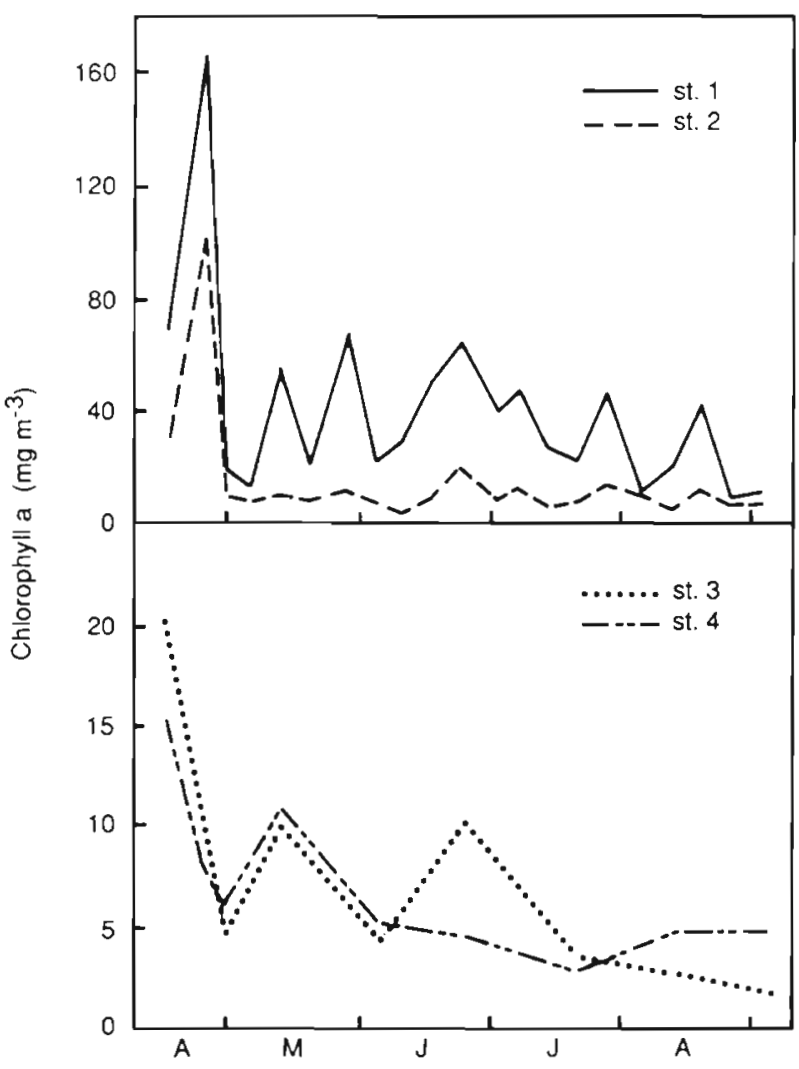

Fig. 3. Phytoplankton biomass ( $\mathrm{mg} \mathrm{chl} \mathrm{a} \mathrm{m}^{-3}$ ) at 4 locations in Roskilde Fjord between April 15 and September 2

biomass $(r=0.16)$ or water temperature $(-0.04$, Table 3). In addition, phytoplankton biomass, phytoplankton productivity and bacterial net production were significantly intercorrelated ( $\mathrm{r}=0.47$ and 0.89 respectively), as were bacterial net production and bacterial biomass $(\mathrm{r}=0.52$, Table 3$)$.

The high levels of community respiration, phytoplankton biomass and phytoplankton productivity at low temperature in spring resulted in a negative correlation with temperature $(\mathrm{r}=-0.04,-0.24,-0.11$, respectively, Table 3 ). Bacterial biomass and bacterial net production showed a less pronounced spring max-

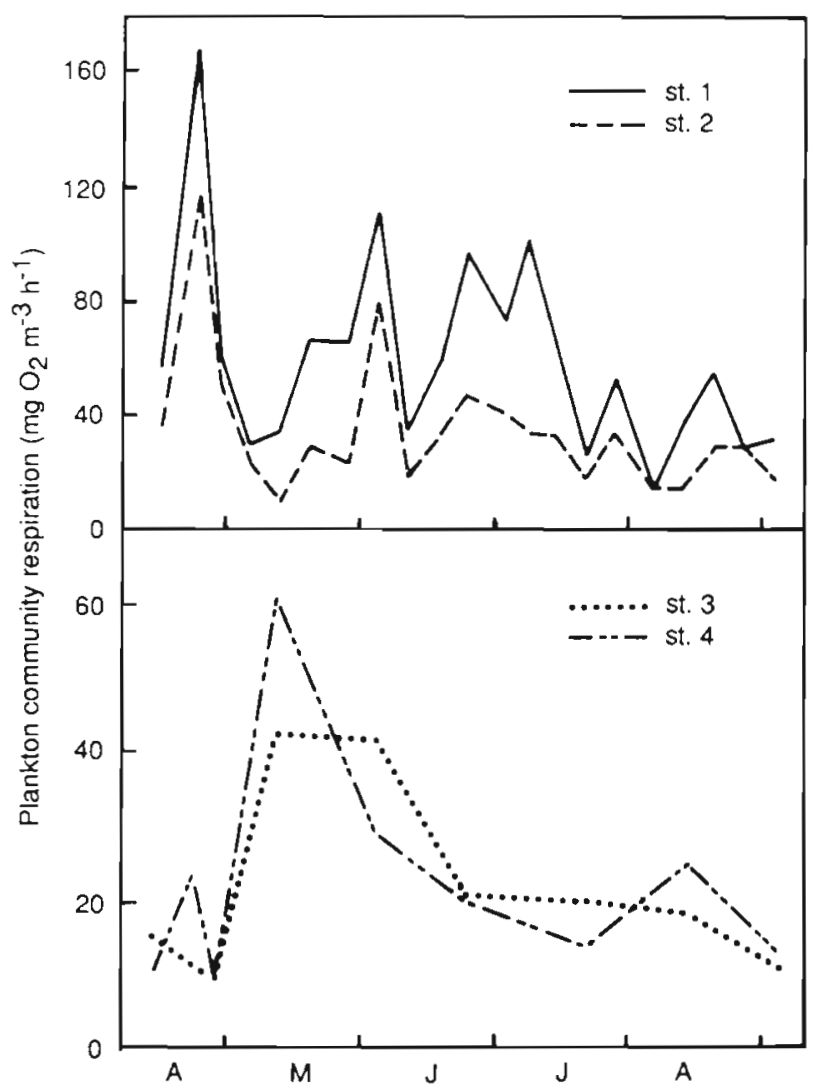

Fig. 4. Plankton community respiration ( $\left.\mathrm{mg} \mathrm{O} \mathrm{O}_{2} \mathrm{~m}^{-3} \mathrm{~h}^{-1}\right)$ at 4 locations in Roskilde Fjord between April 15 and September 2

imum (data not shown) and accordingly, a small positive temperature correlation $(\mathrm{r}=0.39$ and 0.22 respectively, Table 3).

We examined more closely the relationship of community respiration with phytoplankton biomass, phytoplankton productivity and bacterial net production by linear regression analysis (Table 4). Because we had 21 measurements over the season (April to September) at Stns 1 and 2 and only 8 to 9 at Stns 3 and 4, we performed the analysis for Stns 1 and 2 separately, and for all 4 locations together. The relationships of community respiration with phytoplankton biomass and

Table 3. Correlation coefficients between plankton community respiration, phytoplankton biomass (PB) and gross productivity (PGP), bacterial biomass (BB) and net production (BNP), and water temperature in Roskilde Fjord between April 15 and September $2(n=59)$

\begin{tabular}{|c|c|c|c|c|c|}
\hline Variable & PB & PGP & $\mathrm{BB}$ & BNP & Temp. \\
\hline Community respiration & $0.79 \cdots$ & $0.68 \cdots$ & 0.16 & $0.59 \cdots$ & -0.04 \\
\hline Phytoplankton biomass & - & $0.89 \cdots$ & 0.07 & $0.47^{\cdots} \cdot$ & -0.24 \\
\hline Phytoplankton gross productivity & & - & 0.16 & $0.50 \cdots$ & -0.11 \\
\hline Bacterial biomass & & & - & $0.52 \cdots$ & $0.39 \cdots$ \\
\hline Bacterial net production & & & & - & 0.22 \\
\hline
\end{tabular}


Table 4. Linear regression analysis [from the equation $y=a( \pm S E) x+b( \pm S E)$ ] between plankton community respiration (CR) and 3 significantly related variables: phytoplankton biomass (PB), phytoplankton gross productivity (PGP) and bacterial net production (BNP). Relationships were based on measurements at Stn 1, Stn 2 and all 4 locations together in Roskilde Fjord between April 15 and September 2. Units as in Table 2

\begin{tabular}{|c|c|c|c|c|}
\hline Locality & Linear regression & $\mathrm{R}^{2}$ & $\mathrm{n}$ & $\mathrm{F}$ \\
\hline $\operatorname{Stn} 1$ & $\begin{array}{l}\mathrm{CR}=0.76 \cdots(0.16) \mathrm{PB}+29^{\cdots}(8) \\
\mathrm{CR}=0.16^{\prime}(0.06) \mathrm{PGP}+32^{*}(13) \\
\mathrm{CR}=7.8^{\cdots} \cdot(2.6) \mathrm{BNP}+14(16)\end{array}$ & $\begin{array}{l}0.56 \\
0.26 \\
0.33\end{array}$ & $\begin{array}{l}21 \\
21 \\
21\end{array}$ & $\begin{array}{r}23.7 \\
6.5 \\
9.3\end{array}$ \\
\hline $\operatorname{Stn} 2$ & $\begin{array}{l}C R=0.91 \cdots(0.17) \mathrm{PB}+21 \cdots(4) \\
\mathrm{CR}=0.24 \cdots(0.05) \mathrm{PGP}+18^{\prime} \cdots(5) \\
\mathrm{CR}=0.46(3.0) \mathrm{BNP}+33^{*}(13)\end{array}$ & $\begin{array}{l}0.61 \\
0.56 \\
0.01\end{array}$ & $\begin{array}{l}21 \\
21 \\
21\end{array}$ & $\begin{array}{l}30.2 \\
23.8 \\
0.02\end{array}$ \\
\hline Stns $1-4$ & $\begin{array}{l}\mathrm{CR}=0.87 \cdots(0.09) \mathrm{PB}+21 \cdots(3) \\
\mathrm{CR}=0.21 \cdots(0.03) \mathrm{PGP}+2{ }^{\prime} \cdots(4) \\
\mathrm{CR}=7.2 \cdots(1.3) \mathrm{BNP}+12^{*}(6)\end{array}$ & $\begin{array}{l}0.63 \\
0.46 \\
0.35\end{array}$ & $\begin{array}{l}59 \\
59 \\
59\end{array}$ & $\begin{array}{l}96.9 \\
49.2 \\
31.2\end{array}$ \\
\hline
\end{tabular}

productivity were highly significant $(p<0.001)$ at Stns 1 and 2 , and at all locations together. The relationship of community respiration with bacterial net production was significant at Stn 1 and all locations together, but not at Stn 2. Phytoplankton biomass was the best single predictor of community respiration with $R^{2}$ values of $0.56,0.61$ and 0.63 . The relationship of community respiration with phytoplankton biomass and productivity was reliable since the coefficients of respiration to phytoplankton biomass 10.76 to $0.91 \mathrm{mg} \mathrm{O}_{2} \mathrm{mg}^{-1} \mathrm{chl} \mathrm{a}$ $\left.\mathrm{h}^{-1}\right)$ and phytoplankton gross productivity $(0.16$ to 0.24 $\mathrm{mg} \mathrm{O}_{2} \mathrm{mg}^{-1} \mathrm{C}$ ) were both relatively constant and agreed with previous laboratory measurements (see 'Discussion' - 'Phytoplankton and bacteria in pelagic respiration']. In all 9 equations there was a positive 'background' respiration that was significantly different from zero in 8 cases (Table 4). This suggested that phytoplankton or bacteria did not account for all respiratory activity.

We combined the 2 functional groups by multiple linear regression analysis of community respiration versus phytoplankton biomass and bacterial net production or phytoplankton productivity and bacterial net production (Table 5). This analysis reduced the variation in community respiration not accounted for by the 2 independent variables and also reduced the background respiration. The equations including phytoplankton biomass and bacterial net production $\left(\mathrm{R}^{2}=\right.$ $0.62,0.65$ and 0.69 ) were superior to those including phytoplankton productivity and bacterial net production $\left(R^{2}=0.42,0.55\right.$ and 0.57 , Table 5). The main descriptors in the equations were phytoplankton biomass and productivity rather than bacterial net production. The coefficient of respiration to bacterial net production, however, was significant in 4 out of 6 equations, and background respiration had declined to between 7 and $16 \mathrm{mg} \mathrm{O} \mathrm{O}^{-3} \mathrm{~h}^{-1}$ and was only significantly different from zero in 1 of the 6 equations (Table 5).

The measured community respiration was compared with that calculated from the 2 multiple regression equations (Eqs. 5 and 6, Table 5) that comprised the

Table 5. Multiple linear regression analysis [from the equation $y=a_{1}( \pm S E) x_{1}+a_{2}( \pm S E) x_{2}+b$ ( $\pm S E$ )! of plankton community respiration (CR) in relation to phytoplankton biomass (PB) and bacterial net production (BNP) or phytoplankton gross productivity (PGP) and bacterial net production (BNP). Relationships were based on measurements at Stn 1, Stn 2, and all tour locations together in Roskilde Fjord between April 15 and September 2. Units as in Table 2

\begin{tabular}{|c|c|c|c|c|}
\hline Locality & Multiple regression & $\mathrm{R}^{2}$ & $\mathrm{n}$ & $\mathrm{F}$ \\
\hline $\operatorname{Stn} 1$ & $\begin{array}{l}\text { (1) } \mathrm{CR}=0.63 \cdots(0.15) \mathrm{PB}+4.6^{\circ}(2.0) \mathrm{BNP}+8(12) \\
\text { (2) } \mathrm{CR}=0.10(0.06) \mathrm{PGP}+6.1^{*}(2.6) \mathrm{BNP}+7(16)\end{array}$ & $\begin{array}{l}0.65 \\
0.42\end{array}$ & $\begin{array}{l}21 \\
21\end{array}$ & $\begin{array}{r}17.0 \\
6.6\end{array}$ \\
\hline Str 2 & $\begin{array}{l}\text { (3) } \mathrm{CR}=0.91 \cdots(0.17) \mathrm{PB}+1.1(2.0) \mathrm{BNP}+17(8) \\
\text { (4) } \mathrm{CR}=0.24 \cdots(0.05) \mathrm{PGP}+1.8(2.1) \mathrm{BNP}+11(10)\end{array}$ & $\begin{array}{l}0.62 \\
0.57\end{array}$ & $\begin{array}{l}21 \\
21\end{array}$ & $\begin{array}{l}14.7 \\
12.1\end{array}$ \\
\hline Stns $1-4$ & $\begin{array}{l}\text { (5) } \mathrm{CR}=0.72 \cdots(0.09) \mathrm{PB}+3.4 \cdots(1.0) \mathrm{BNP}+11 \cdots(4) \\
\text { (6) } \mathrm{CR}=0.15 \cdots(0.03) \mathrm{PGP}+4.1 \cdots(1.3) \mathrm{BNP}+9(5)\end{array}$ & $\begin{array}{l}0.69 \\
0.55\end{array}$ & $\begin{array}{l}59 \\
59\end{array}$ & $\begin{array}{l}62.6 \\
34.3\end{array}$ \\
\hline
\end{tabular}


entire data set (Fig. 5). The precision of the predictions were such that 76 to $85 \%$ of the measured values were within $\pm 50 \%$ of those estimated. There was no systematic pattern of residual variation among stations or size of community respiration (Fig 5), or with time or

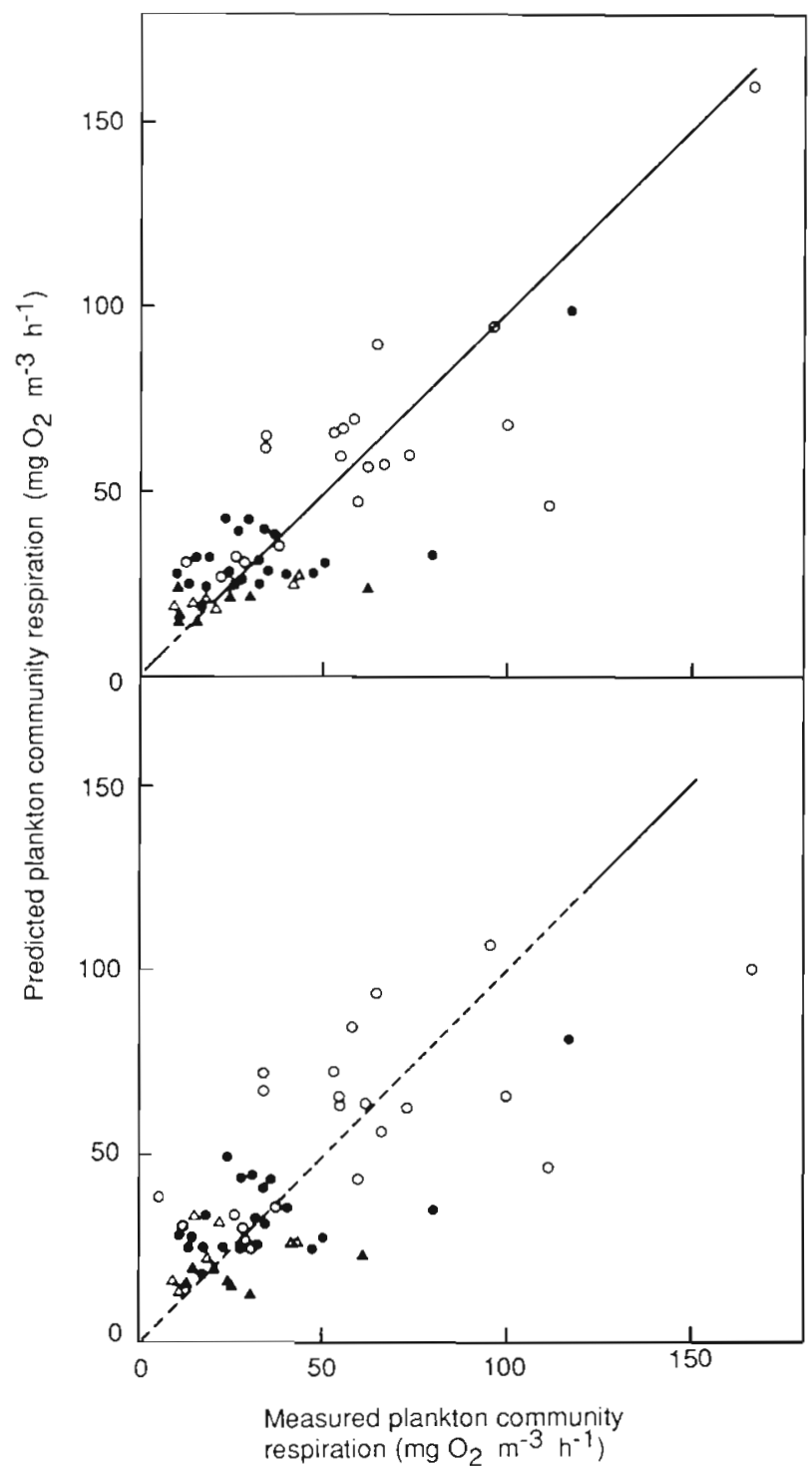

Fig. 5. Measured and predicted plankton community respiration ( $\mathrm{mg} \mathrm{O} \mathrm{O}_{2} \mathrm{~m}^{-3} \mathrm{~h}^{-1}$ ) at 4 locations in Roskilde Fjord: Stns 1 $(0) ; 2(\bullet) ; 3(\Lambda) ; 4(\Lambda)$. Upper: Predicted from phytoplankton biomass and bacterial net production (Eq. 5 Table 5). Lower: Predicted from phytoplankton gross productivity and bacterial net production (Eq. 6, Table 5)

size of the independent variables (data not shown). However, there was still a substantial variability of community respiration unaccounted for. Considering the measuring errors of community respiration and the independent variables (Table 2) and the possible seasonal variations in the coefficients of respiration to phytoplankton biomass, phytoplankton productivity and bacterial net production it is doubtful whether this prediction can be improved by introducing additional independent variables such as zooplankton biomass.

\section{Phytoplankton and bacterial respiration and overall oxygen balance}

The coefficients of respiration to phytoplankton biomass, phytoplankton productivity and bacterial net production are summarized in Table 6 based on the

Table 6 . Mean and range of the coefficients of respiration $(R)$ to phytoplankton biomass (PB), phytoplankton gross productivity (PGP) and bacterial net production (BNP) based on the significant values from multiple linear regression analysis (Table 5) The ratios of phytoplankton respiration to gross productivity (R/PGP) and bacterial respiration to net production (R/BNP) were calculated assuming a molar ratio of oxygen to carbon of 1.25 (Langdon 1988). $\mathrm{R} / \mathrm{PB}=\mathrm{mg} \mathrm{O} \mathrm{mg}^{-1} \mathrm{chl} \mathrm{a} \mathrm{h}^{-1}$

\begin{tabular}{|cccc|}
\hline & $\mathrm{R} / \mathrm{PB}$ & $\mathrm{R} / \mathrm{PGP}$ & $\mathrm{R} / \mathrm{BNP}$ \\
\hline Mean & 0.76 & 0.060 & 1.4 \\
Range & $0.63-0.91$ & $0.046-0.073$ & $1.0-1.8$ \\
\hline
\end{tabular}

values obtained from multiple linear regression analysis (Table 5). The mean phytoplankton biomass specific respiration was $0.76 \mathrm{mg} \mathrm{O}_{2} \mathrm{mg}^{-1} \mathrm{chl} \mathrm{a} \mathrm{h}^{-1}$ and the proportion of dark respiration to light saturated gross productivity was 0.060 , assuming a molar ratio of oxygen to carbon of 1.25 (Langdon 1988).

The estimated proportion of bacterial respiration to net production was 1.4 (Table 6) corresponding to a mean growth yield of bacteria (bacterial net production/bacterial gross production) of $42 \%$. The growth yield is sensitive to the factors used to convert thymidine incorporation into number of cells produced and bacterial volume into carbon biomass. Both conversion factors were derived from studies in Roskilde Fjord, and the 2 factors in combination are also reasonable according to recent evaluations by Cole et al. (1989) based on carbon balances from Mirror Lake. Nevertheless, the conversion factors produce considerable uncertainty to the estimate of growth yield (see Discussion). The 2 conversion factors, however, will not affect the following estimated of the contribution of bacteria to community respiration provided that they do not vary systematically with the magnitude of thymidine incorporation.

We estimated phytoplankton, bacterial and 'background respiration at Stns 1 and 2 using the 2 multiple regression equations (Eqs. 5 and 6, Table 5). The calculations suggested that phytoplankton, on average, were responsible for 43 and $41 \%$ of community respi- 
ration at $\operatorname{Stn} 1$, bacteria for 35 and $42 \%$, and 22 and $17 \%$ of the respiration were not accounted for. At Stn 2 , the estimated mean contributions were 26 and $29 \%$ for phytoplankton, 38 and $43 \%$ for bacteria and 28 and $36 \%$ were not accounted for.

The overall oxygen balance for the pelagic waters and the underlying sediment was estimated for the period April 15 to September 2 (Table 7). We acknowledge that there are several short-commings in the

Table 7. Pelagic gross production, pelagic and benthic oxygen consumption integrated over 140 d between April 15 and September 2 at 4 locations in Roskilde Fjord. Pelagic gross production and respiration were integrated over the depth of the water column (Table 1). Pelagic gross production was converted from carbon to oxygen assuming a $\mathrm{PQ}$ (photosynthetic quotient) ratio of 1.25 . Benthic respiration was estimated from Kamp-Nielsen, Nors \& Kanneworff (unpubl. data). All units in $\mathrm{g} \mathrm{O}_{2} \mathrm{~m}^{-2}(\mathrm{P} / \mathrm{R}=$ Pelagic gross production: pelagic + benthic respiration)

\begin{tabular}{|lrrrr|}
\hline Variable & Stn 1 & Stn 2 & Stn 3 & Stn 4 \\
\hline Pelagic gross production & 1660 & 945 & 836 & 672 \\
Pelagic respiration & 821 & 529 & 423 & 615 \\
Benthic respiration & 370 & 330 & 268 & 229 \\
P/R & 1.39 & 1.10 & 1.21 & 0.80 \\
\hline
\end{tabular}

procedure because the whole year was not covered and pelagic measurements may miss short-lived peaks in the processes, whereas there is some built-in integration in the benthic processes which may take a long time to completely consume a sedimented phytoplankton bloom. Annual values will be higher than those presented here, particularly the respiration values that are likely to exceed phytoplankton productivity during the winter Phytoplankton productivity exceeded pelagic respiration at Stns 1 to 3 and they approximately matched each other at the deep and less productive Sth 4 . Pelagic respiration was between 1.6 and 2.7 -fold higher than the benthic respiration. Finally, the 3 inner locations (Stns 1 to 3 ) showed a higher phytoplankton productivity than the combined respiration in the water column and the sediment whereas this balance was reversed at $\operatorname{Stn} 4$.

\section{DISCUSSION}

\section{Pelagic and benthic respiration}

Rates of plankton community respiration in. Roskilde Fjord were among the highest ever recorded for estuarine and coastal marine ecosystems (Table 3 in. Hopkinson 1985) and resembled rates for eutrophic lakes (Schwaerter et al. 1988). At the 2 most eutrophic localities, mean $\left(0.6\right.$ to $\left.1.4 \mathrm{~g} \mathrm{O}_{2} \mathrm{~m}^{-3} \mathrm{~d}^{-1}\right)$ and maximum rates of oxygen consumption (2.8 to $4.0 \mathrm{~g} \mathrm{O}_{2} \mathrm{~m}^{-3} \mathrm{~d}^{-1}$ ) were sufficiently fast to induce marked diel variations of oxygen concentrations and severe oxygen depletion during night and during cloudy days with calm weather and limited vertical mixing and atmospheric exchange (Borum et al. unpubl.). Thus, if these maximum rates were maintained and proceeded without new supply of oxygen they would consume the oxygen pool of initially air-saturated water within 2 to $4 \mathrm{~d}$. Because wind action and solar illumination vary greatly, sporadic measurements are not suitable to describe variations in oxygen concentrations in the shallow environment. Nevertheless, bimonthly monitoring cruises in the estuary did demonstrate severe oxygen depletion $20 \mathrm{~cm}$ above the sediment in the most eutrophicated inner parts ( $\mathrm{Stn}$ 1:2.6 $\mathrm{mg} \mathrm{O}_{2} 1^{-1}$ on June 24; $\operatorname{Stn} 2: 0.8 \mathrm{mg} \mathrm{O}_{2} \mathrm{l}^{-1}$ on April 15 and $2.7 \mathrm{mg} \mathrm{O}_{2} \mathrm{l}^{-1}$ on June 24) whereas oxygen concentrations were always above $80 \%$ saturation in bottom waters of the less nutrient-rich outer parts (Stn 3 and 4; Roskilde County unpubl.). Interestingly, the lowest oxygen concentration $\left(0.8 \mathrm{mg} \mathrm{O}_{2} \mathrm{l}^{-1}\right)$ measured in the bottom waters occurred at low temperature $\left(5^{\circ} \mathrm{C}\right)$ in April and coincided with the phytoplankton bloom and maximum rates of community respiration. Oxygen concentrations closer to the sediment surface will be lower than the above measurements and more critical conditions in between the bimonthly measurements are also possible. Kanneworff (unpubl.) observed episodic destruction of the benthic fauna at Stn 2 and species diversity was permanently low at Stn 1 .

Pelagic respiration greatly exceeded benthic respiration in Roskilde Fjord. The short distance to the sediment in the shallow estuary, on one hand, limits the vertical extension of the pelagic respiration process and should enhance sedimentation rates. On the other hand, frequent mixing and resuspension of the sediment may eventually increase the residence time of organic matter in the water column. The high phytoplankton productivity in the estuary is also expected to increase the importance of the pelagic community in oxidizing organic material (cf. Hargrave 1973. Hopkinson 1985). Close coupling between pelagic production and pelagic respiration was demonstrated by their similar variations in time and space (Jensen et al. 1987) and by the ability to predict pelagic respiration from phytoplankton biomass and productivity. Moreover, the proportion of pelagic to benthic respiration clearly increased with higher phytoplankton productivity in the inner parts of the estuary when corrected for changes in water depths (Tables 2 and 7 ).

We explain this pattern by the following conditions. At high phytoplankton densities greater proportions of phytoplankton gross productivity are likely to be 
respired by phytoplankton because of poor light penetration in the water column and because phytoplankton respiration constitutes a large proportion of community respiration. Respiration of sediments receiving a surplus of degradable organic material, on the other hand, is likely to be constrained by oxygen availability because of slow diffusive supply. Moreover, benthic macroinvertebrates are important for ventilation of sediments and they often disappear under very eutrophic conditions. The benthic fauna, for example, was greatly decimated at Stn 1.

The predictions of pelagic respiration established for Roskilde Fjord were based on easily accessible independent variables and the predictions probably apply to other phytoplankton-rich, shallow, and well-mixed temperate waters. However, they need to be tested and eventually altered to be of more general use in areas with different mixing patterns and smaller phytoplankton productivities. In particular, temporal and spatial separations between photosynthesis and respiration will be more significant in larger and deeper stratified waters (Officer et al. 1984). Also, there may be other fundamental differences because of the highly eutrophic conditions in Roskilde Fjord compared with most other marine systems

\section{Phytoplankton and bacteria in pelagic respiration}

Phytoplankton and bacteria were the 2 main functional groups of respiring organisms in the plankton community in Roskilde Fjord according to our estimates. Pelagic respiration not accounted for by these organisms was estimated to mean values between 17 and $36 \%$ of total respiration at the 2 most eutrophic localities, and in addition to random residual variation involve respiration of heterotrophic flagellates, ciliates and crustacean zooplankton. The overall importance of phytoplankton and bacteria in plankton respiration was supported in several ways. Sizefractionation of pelagic respiration in Roskilde Fjord at Stns 1 and 2 (Jensen et al. unpubl.) showed the same dominant contribution of phytoplankton and bacteria and the results were quantitatively in close agreement with the regression estimates. Previous size-fractionation experiments in eutrophic marine waters and in lakes (Williams 1984, Schwaerter et al. 1988) show the high respiratory activity of the 2 functional groups and stress the major importance of free-living bacteria in utilizing dissolved organic compounds.

The maximum community respiration occurred during the phytoplankton spring bloom at low temperatures $(5$ to $7^{\circ} \mathrm{C}$ ). Pronounced spring blooms are typical of most temperate coastal waters and the highest respiratory rates are likely to be associated with the development or collapse of these blooms (Lancelot \& Billen 1984). Risks of oxygen depletion are usually searched for during high temperatures and stratified conditions during summer and early autumn. Severe oxygen depletion, however, may develop during all major bloom events in conjunction with short-term reduction of turbulent mixing (e.g. the observations at Stns 1 and 2). Recent observations of oxygen depletion in the Danish Kattegat and Great-Belt area during the early spring bloom (Nielsen 1988), also support this view

Estimates of phytoplankton and bacterial respiration derived from the regression models were in overall agreement with previous laboratory measurements. The mean biomass specific respiration rate for phytoplankton (0.76 $\mathrm{mg} \mathrm{O}_{2} \mathrm{mg}^{-1} \mathrm{chl} \mathrm{a} \mathrm{h}^{-1}$, Table 6) was within the range of 0.1 to $1 \mathrm{mg} \mathrm{O}_{2} \mathrm{mg}^{-1} \mathrm{chl} \mathrm{a} \mathrm{h}^{-1}$ given by Harris (1978) and corresponded with the mean maintenance respiration of $0.66 \mathrm{mg} \mathrm{O}_{2} \mathrm{mg}^{-1} \mathrm{chl} \mathrm{a} \mathrm{h}^{-1}$ for 12 species in laboratory culture compiled by Langdon (1988, his Table 6). The proportion of phytoplankton respiration to light saturated productivity derived from the regression models was 0.060 (Table 6). Again, this value agrees with proportions found by other authors: 0.05 to 0.10 (Laws 1975), 0.04 to 0.07 (Harris \& Piccinin 1977), and 0.06 (Holligan 1984). Phytoplankton respiration is composed of two components: maintenance respiration, which is perhaps variable among species, and growth respiration, which may be proportional to growth (Langdon 1988). Biomass and production specific respiration rates may therefore vary seasonally with species composition, growth dynamics, and light availability of the phytoplankton assemblage. This would produce considerable scatter in the relationship between measured and estimated community respiration.

The mean ratio of respiration to net production of bacteria obtained by multiple regression analysis was 1.4 (Table 6) and mean bacteria growth yield was $42 \%$. The mean bacterial growth yield attained by sizefractionation technique in Roskilde Fjord was $46 \%$ (Sand-Jensen et al. unpubl.). We acknowledge that there are many assumptions and potential errors associated with these growth yield estimates including: the conversion factors for estimating bacterial net production, the generated regression models, the oxygen/ carbon ratios applied, and analytical errors. Nevertheless, the estimates of bacterial growth yield attained are clearly reasonable and within the wide limits of 20 to $80 \%$ cited by most previous authors (cf. Bjornsen 1986). Bacterial growth yield may vary depending on substrate composition and its carbon/nitrogen ratio (Goldmann et al. 1987) and temperature. Methodological problems, however, also affect the results. Very high estimates (65 to $78 \%$ ) have been obtained in incubations of a few hours of bacteria with radio- 
labelled substrates but they can be viewed as estimates of uptake efficiences rather than growth yield (Bjørnsen 1986). By contrast, mean growth yields of $21 \%$ were obtained by carbon mass balances of bacteria cultures supplied with filtered water from Roskilde Fjord (Bjørnsen 1986). Only future direct measurements can confirm our findings and reveal the natural variations of bacterial growth yield.

\section{CONCLUSIONS}

Pelagic respiration was very high and exceeded benthic respiration in the phytoplankton-rich inner parts of Roskilde Fjord. We argue that pelagic respiration increased relative to benthic respiration with increasing eutrophication. This was because the proportion of gross productivity respired by phytoplankton increased, oxygen availability constrained benthic and not pelagic respiration, and benthic macroinvertebrate populations were reduced at the most eutrophic site.

Pelagic respiration was closely related to seasonal and spatial changes in biomass and gross production of phytoplankton and net production of bacteria in Roskilde Fjord. The relationship to bacterial biomass was poor, probably because of variable growth rates and the presence of many inactive bacteria. The relationship to temperature was negative because pelagic respiration peaked during the spring bloom of phytoplankton. High pelagic respiration rates are therefore associated with formation and collapse of phytoplankton blooms, independent of temperature and the time of year. Multiple regression models of community respiration versus biomass or gross production of phytoplankton and net production of bacteria based on 59 data set provided mean estimates of phytoplanktion respiration $10.76 \mathrm{mg}$ $\mathrm{O}_{2} \mathrm{mg}^{-1} \mathrm{chl} a \mathrm{~h}^{-1}, 6.0 \%$ of gross productivity) and bacterial growth yield $(42 \%)$ that corresponded with previous laboratory estimates. We acknowledge that these values may change with time and space because of variable species composition and resource availabilities.

Acknowledgements. This study was supported by the Danish Environment Protection Agency. We thank F. Pedersen, P. K. Bjernsen and $\mathrm{H}$. J. Hansen for help during the work and P. K Bjørnsen and $M$. Søndergaard for valuable suggestions on the manuscript

\section{LITERATURE CITED}

Anon. (1983). Dansk Standard. DS.293. Vandundersøgelser. Planktonalgers kulstofassimilation 1 inkubator med ${ }^{14} \mathrm{C}$ metoden, Dansk Standardiseringsrad, Copenhagen, p. 1-17 (in Danish)

Anon. (1984). Iltsvind og fiskedød i 1981. The National Agency of Environmental Protection, Denmark (in Danish)
Azam, F., Fenchel, T., Field, J. G., Gray, J. S., Meyer-Reil, L. A., Thingstad, F. (1983). The ecological role of watercolumn microbes in the sea. Mar Ecol. Prog. Ser. 10: $257-263$

Bjornsen, P. K. (1986). Bacterioplankton growth yield in continuous seawater cultures. Mar Ecol. Prog. Ser. 30: $191-196$

Borum, J. (1985). Development of epiphytic communities on eelgrass (Zostera marina) along a nutrient gradient in a Danish estuary. Mar. Biol. 87: 223-241

Bryan, J. R., Riley, J. P., Williams, P. J., le B. (1976). A Winkler procedure for making precise measurements of oxygen concentrations for productivity and related studies. J. exp. mar. Biol. Ecol. 21. 191-197

Cole, J. J., Caraco, N. F., Strayer, D. L., Ochs, C., Nolan, S. (1989). A detailed organic carbon budget as an ecosystem level calibration of bacterial respiration in an oligotrophic lake during midsummer Limnol Oceanogr. 34: 286-296

Fenchel, T (1988). Marine plankton food chains. A. Rev. Ecol. Syst. 19: $19-38$

Fuhrman. J. A. (1981). Influence of method on the apparent size distribution of bacterioplankton cells: epifluorescence microscopy compared to scanning electron microscopy. Mar. Ecol. Prog. Ser. 5: 103-106

Fuhrman, J. A., Azam, F. (1980). Bacterioplankton secondary production estimates for coastal waters off British Colombia, Antarctica and California. Appl. envir Microbiol. 39: 1085-1095

Goldman, J. C., Caron, D. A., Dennett, M. R. (1987). Regulation of gross growth efficiency and ammonium regeneration in bacteria by substrate C:N ratio. Limnol. Oceanogr. 32: $1239-1252$

Griffith, P. C. (1984). A high-precision respirometer for measuring small rates of change in the oxygen concentration of natural waters. Limnol. Oceanogr 33:632-638

Hargrave, B. T. (1973). Coupling carbon flow through some pelagic and benthic communities. J. Fish. Res. Bd Can, 30: $1317-1326$

Harris, G. P. (1978). Photosynthesis, productivity and growth: the physiological ecology of phytoplankton. Arch. Hydrobiol. (Beih. Ergebn. Limnol.) 10: 1-171

Harris, G. P., Piccinin, B. B. (1977). Photosynthesis by natural phytoplankton populations. Arch. Hydrobiol. 80: 405-457

Hobbie, J. E., Daley, R. J., Jasper, S. (1977). Use of nucleopore filters for counting bacteria fluorescence rnicroscopy. Appl. envir Microbiol. 33: 1225-1228

Holligan, P. M. (1984). Photosynthesis, respiration and nitrogen supply of plankton populations in stratified frontal and tidally mixed shelf waters. Mar. Ecol. Prog. Ser. 17 $201-213$

Hopkinson, C. S., Jr (1985). Shallow water benthic and pelagic metabolism: evidence of heterotrophy in the nearshore Georgia Bight. Mar Biol. 87: 19-32

Jensen, L. M., Marcher, S., Hansen, M. (1987). Produktion og omsætning of organisk stof i de frie vandmasser i Roskilde Fjord. MS. Thesis, Freshwater Biological Laboratory, University of Copenhagen (in Danish)

Jespersen, A., Kristoffersen, K. (1987). Measurements of chlorophyll-a from phytoplankton using ethanol as extraction solvent. Arch. Hydrobiol. 109: 445-454

Lancelot, C. Billen, G. (1984). Activity of heterotrophic bacteria and its coupling to primary production during the spring phytoplankton bloom in the southern bight of the North Sea Limnol. Oceanogr. 29: 721-730

Langdon, C. (1984). Dissolved oxygen monitoring system using a pulsed electrode: design, performance and evaluation. Deep-Sea Res. 31. 1357-1367 
Langdon, C. (1988). On the causes of interspecific differences in the growth-irradiance relationship for phytoplankton. 2. A general review. J. Plankton Res. 10: 1291-1312

Larsson, U., Hagström, A. (1979). Phytoplankton exudate release as an energy source for the growth of pelagic bacteria. Mar. Biol. 52: 199-206

Larsson, U., Hagström, A. (1982). Fractionated phytoplankton primary production, exudate release, and bacterial production in a Baltic eutrophication gradient. Mar. Biol. 67: $57-70$

Larsson, V R., Elmgren, R., Wulff, F. (1985). Eutrophication and the Baltic Sea: causes and conseqenses. Ambio 14 $10-14$

Laws, E. A. (1975). The importance of respiration losses in controlling the size distribution of marine phytoplankton. Ecology 56: 419-427

Nielsen, G. AE. (1988). Årsrapport 1987. The National Agency of Environmental Protection, Denmark (in Danish)

Nielsen, G. Æ., Jacobsen, T. S., Gargas, E., Buch, E. (1981) The Belt Project. Evaluation of physical, chemical and biological measurements. The National Agency of Environmental Protection, Denmark

Officer, C. B., Biggs, R. B., Toft, J. L., Cronin, L. E., Tyler, M. A., Boynton, W. R. (1984). Chesapeake Bay anoxia: origin, development and significance. Science, N.Y 223 $22-27$

Riemann, B. (1984). Determining growth rates of natural assemblages of freshwater bacteria by means of ${ }^{3} \mathrm{H}$-thymidine incorporation into DNA: comments on methodology. Arch. Hydrobiol. (Beih. Ergebn. Limnol.) 19: 67-80

Riemann, B., Bjornsen, P. K., Newell, S., Fallon, R. (1987). Calculation of cell production of coastal marine bacteria based on measured incorporation of ${ }^{3} \mathrm{H}$-thymidine. Limnol. Oceanogr. 32: 471-476

This article was submitted to the editor
Riemann, B., Nielsen, P., Jeppesen, M., Marcussen, B., Fuhrman, J. A. (1984). Diel changes in bacterial biomass and growth rates in coastal environments, determined by means of thymidine incorporation into DNA, frequency of dividing cells (FDC), and microautoradiography. Mar. Ecol. Prog. Ser 17: 227-235

Schwaerter, S., Sondergård, M., Riemann, B., Jensen, L. M. (1988). Respiration in eutrophic lakes: the contribution of bacterioplankton and bacterial growth yield. J. Plankton Res. 10: $515-531$

Steele, J. H. (1974). The structure of marine ecosystems. Blackwell Scientific Publications, Oxford

Talling, J. F. (1973). The application of some electrochemical methods to the measurement of photosynthesis and respiration in freshwaters. Freshwat. Biol. 3: 335-362

Velji, M. I. (1983). Improved microscopic enumeration of attached aquatic bacteria following deflocculant and ultrasound treatment. MS. Thesis, Simon Fraser Un:versity, Canada

Vermaat, J. E., Sand-Jensen, K. (1987). Survival, metabolism and growth of Ulva lactura under winter conditions; a laboratory study of bottle necks in the life cyclus. Mar. Biol. 95: $55-61$

Westernhagen, H. V., Hickel, W., Bauerfeind, E., Niermann, V. Krünche, I. (1986). Sources and effects of oxygen deficiencies in the south-eastern North Sea. Ophelic 26: $457-473$

Williams, P. J., le B. (1981). Microbial contribution to overall marine plankton metabolism: direct measurements of respiration. Oceanol. Acta. 4: 359-364

Williams, P. J., le B. (1984). A review of measuremen:s of respiration rates of marine plankton populations. In: Hobbie J E., Williams, P. J., le B. (eds.) Heterotrophic activity in the sea. Plenum Press, New York, p. 357-389

Manuscript first received: June 13, 1989

Revised version accepted: December 21, 1989 